\title{
Analyses of plumage coloration and genetic variation confirm the hybridization of Pipra fasciicauda and Pipra aureola in the Brazilian Amazon basin
}

\section{Sampaio, Larissa}

2020-04

Sampaio , L , Ferraz , D O , Moreira da Costa , A C , Aleixo , A , Cerqueira , P V , Araripe , J \& do Rego , P S 2020 , ' Analyses of plumage coloration and genetic variation confirm the hybridization of Pipra fasciicauda and Pipra aureola in the Brazilian Amazon basin ' , Journal of Ornithology , vol. 161 , no. 2 , pp. 503-508 . https://doi.org/10.1007/s10336-020-01744-1

http://hdl.handle.net/10138/324747

https://doi.org/10.1007/s10336-020-01744-1

unspecified

acceptedVersion

Downloaded from Helda, University of Helsinki institutional repository.

This is an electronic reprint of the original article.

This reprint may differ from the original in pagination and typographic detail.

Please cite the original version. 
Analyses of plumage coloration and genetic variation confirm the hybridization of Pipra fasciicauda and Pipra aureola in the Brazilian Amazon basin

Larissa Sampaio $^{1}$, Dnilson Oliveira Ferraz ${ }^{1}$, Ana Carolina Moreira da Costa $^{1}$, Alexandre Aleixo ${ }^{2}$, Pablo Vieira Cerqueira $^{3}$, Juliana Araripe ${ }^{1}$, Péricles Sena do Rêgo ${ }^{1,4}$

${ }^{1}$ Instituto de Estudos Costeiros, Universidade Federal do Pará, Bragança, Pará, Brazil;

${ }^{2}$ Coordination of Zoology, Museu Paraense Emílio Goeldi, Belém, Pará, Brazil;

${ }^{3}$ Laboratory of Ornithology and Molecular Biology, Museu Paraense Emílio Goeldi/Universidade Federal do Pará, Curso de Pós-Graduação de Zoologia, Belém, Pará, Brazil;

${ }^{4}$ Correspondence and current address: Péricles Sena do Rêgo, Laboratório de Genetica e Conservação, Campus Universitário de Bragança, Universidade Federal do Pará, Bragança-PA, 68600-000, Brazil, Telephone number: 5591 34251209, e-mail address: periclessena@yahoo.com.br

\section{ORCID}

Alexandre Aleixo http://orcid.org/0000-0002-7816-9725

Juliana Araripe http://orcid.org/0000-0002-8014-3081

Pablo Vieira Cerqueira https://orcid.org/0000-0002-7311-6229

Péricles Sena do Rêgo http://orcid.org/0000-0002-4537-946X

\section{Acknowledgments}

We thank the curators and curatorial assistants of the Goeldi Museum in Belém and the National Institute for Amazonian Research (INPA) in Manaus for allowing us to obtain tissue samples from the specimens under their care. AA is supported by a CNPq research productivity fellowship, \#306843/2016-1. PVC is supported by a CAPES (the Brazilian Higher Education Training Program) doctoral fellowship, \#1537057. We also thank CAPES for financial support throughout this study, the UFPA Institute of Coastal Studies and Graduate Program in Environmental Biology, Stephen Ferrari for the revision of the text, and Ciro Albano for providing the photograph of Pipra aureola used in the manuscript. We finally express our acknowledgments to Liviu Parau and one anonymous reviewer for providing valuable suggestions to improve the manuscript. 


\section{Abstract}

2 The present study aimed to confirm the occurrence of a hybridization event between the Band-tailed Manakin

3 (Pipra fasciicauda) and the Crimson-hooded Manakin (Pipra aureola), based on the existence of a specimen

4 that presents morphological traits of both taxa. We analyzed 297 taxidermized skins of adult males of the two

5 species, including the potential hybrid. We also analyzed the mitochondrial (ND2, ND3 e COI) and nuclear

6 (FGB-I5, MB-I2 e GAPDH-I3) genes of 12 adult specimens of the two taxa, diagnosed phenotypically, in

7 addition to the potential hybrid. The analyses of the plumage indicated that the potential hybrid has an

8 intermediate pattern of white banding on the tail that is less extensive than that found in Pipra fasciicauda, but

9 that its other phenotypic traits are characteristic of Pipra aureola. The molecular topologies revealed two clades,

10 one that groups $P$. aureola together with the potential hybrid, and the other, that corresponds to $P$. fasciicauda.

11 These findings allowed us to confirm the occurrence of a process of hybridization and potential introgression

12 through secondary events in the P. aureola lineage.

13

14 Key words: Hybrids; intrageneric hybridization; introgression; manakins; Pipridae; secondary contact 


\section{Introduction}

Hybridization and introgression events are common in birds, especially in closely-related species (De Kort et al. 2002). These events have been interpreted as the result of many different processes, including the influence of natural stimuli, the lack of potential mates of the same species or errors in conspecific recognition. Grant and Grant (1992) concluded that hybridization events are extremely common in birds, occurring in approximately one in every ten species, a process that may support the formation of new species (Toews et al. 2018). In a recent study, Weir et al. (2015) concluded that hybridization in Amazonian birds may be a consequence of the slow evolution of reproductive isolation, given that even taxa known to have diverged at least four million years ago may hybridize when they come into contact.

The species of the family Pipridae, known as manakins, are a group of small Neotropical birds with an ample distribution in the Amazon basin. There is a number of reported cases of hybridization in piprids, including intra- and inter-generic matings, confirmed by both morphological traits and genetic analyses (Brumfield et al. 2001). Both types of hybridization have been recorded in the genus Pipra, with intergeneric matings between the Wire-tailed Manakin (Pipra filicauda) and White-crowned Manakin (Pseudopipra pipra) (Graves 1993), Crimson-hooded Manakin (Pipra aureola) and Flame-crested Manakin (Heterocercus linteatus) (Parkes 1961), and an intrageneric case between P. aureola and P. filicauda, a hybrid that was initially identified as Pipra heterocerca (Haffer 1970).

Although no evidence of hybridization involving the Band-tailed Manakin (Pipra fasciicauda) has been reported previously, an enigmatic specimen from the municipality of Acará, in the northern Brazilian state of Pará, raised the possibility of hybridization in this species. In the present study, we investigated the probable process of intrageneric hybridization/introgression between the sister species $P$. fasciicauda and P. aureola, based on the analysis of plumage traits and molecular data.

\section{Material and Methods}

During ann expedition to survey Pipra fasciicauda in the area of Acará, a known locality for the occurrence of this species (Novaes and Lima 2009), PVC detected several individuals with plumage slightly different from that of a typical $P$. fasciicauda and more similar to $P$. aureola. The plumage of these individuals was more reddish in general than that of $P$. fasciicauda, and lacked the white band on the tail. Given these characters, one specimen was collected for a more systematic evaluation, based on plumage patterns and 
molecular data, in addition to a specimen with typical P. fasciicauda plumage. Specimen collection was authorized by the Chico Mendes Institute of Biodiversity-ICMBio, through protocol number 44560-3. The presence of $P$. aureola in this region was never well documented, but there are some recent reports from this region, and the habitat in the study area appears to be favorable to the contact of the two species, given that it represents a transition between 'terra firme' forest and 'várzea' (swamp) forests with Heliconia sp.

We analyzed the plumage patterns in 297 taxidermized skins of male manakins deposited in the ornithological collection of the Emílio Goeldi Museum (MPEG: Museu Paraense Emílio Goeldi), in Belém. These specimens included 190 Pipra fasciicauda, 106 Pipra aureola, and one individual with an intermediate phenotype (the putative hybrid) between $P$. fasciicauda and $P$. aureola. We classified the plumage of the head, throat, breast, and flanks, using Smithe's (1975) color catalog, and determined the presence and configuration of the white band in the tail to summarize the phenotypic differences between the study species.

We complemented this analysis of the plumage with genetic analyses of 13 samples of muscle tissue, including nine $P$. fasciicauda, three $P$. aureola, and the putative hybrid. These specimens were collected from six localities within the geographic ranges of the respective species (Fig 1), and were provided by the Emílio Goeldi Museum (Online Resource 1). We extracted total genomic DNA using the Wizard Genomic DNA Purification kit (Promega Corporation), following the protocol provided by the manufacturer. We used Polymerase Chain Reaction (PCR) to amplify three mitochondrial markers (NADH dehydrogenase subunit 2 (ND2), NADH dehydrogenase subunit 3 (ND3), Cytochrome oxidase subunit I, COI), and three nuclear regions, intron 5 of the Beta-fibrinogen gene (FGB-I5), intron 2 of the Myoglobin (MB-I2), and Glyceraldehyde 3phosphate dehydrogenase (GAPDH-I3). We determined the nucleotide sequences in an ABI 3500 automatic sequencer (Applied Biosystems). We provide information on the primers and amplification conditions of each gene or region analyzed in the present study in the Electronic Supplementary Material (Online Resource 2).

We edited the sequences in the FASTA format, corrected them in BioEdit version 7.1.3 (Hall 1999), and aligned them automatically in CLUSTAL-W (Thompson et al 1994), an option from the above-mentioned software . We codified the double peaks observed in the nuclear markers, which were confirmed as heterozygous sites, based on the IUPAC nucleotide nomenclature. We concatenated the genes in Sequence Matrix version 1.7.8 (Vaidya et al. 2011). We further selected the optimum nucleotide substitution model in PartitionFinder, version 1.1.1 (Lanfear et al. 2012), and identified the best partition of these data for the construction of the Bayesian Inference topology, based on the Akaike Information Criterion, in MrBayes 3.2.0 (Huelsenbeck and 

Ronquist 2001). We rooted the phylogenetic tree (multilocus and mitochondrial) at $P$. filicauda $(\mathrm{N}=4)$, using samples provided by the National Institute for Amazonian Research (INPA).

\section{Results}

Our morphological data indicate that the specimen collected in the region of Acará shares some plumage traits with the males of both Pipra fasciicauda and Pipra aureola, but shows more similarities to the latter species (Table 1). In the ventral view of the tail of the potential hybrid, the specimen presents the continuous white band typical of Pipra fasciicauda, while in the dorsal view, only the three outer rectrices have white marks, and no white coloration is exhibited when the bird is perched in a natural position. The flanks of the potential hybrid have more black than P. fasciicauda, and the undertail coverts are almost entirely black, as in P. aureola, also masking the white band of the rectrices when the bird is perched naturally, while in Pipra fasciicauda, only a small distal portion is black, displaying the diagnostic white band of this species. More subtle traits, such as the plumage of the head, throat, breast, the rudimentary blackish flanks, and the presence of a partial white band indicate that Pipra aureola and Pipra fasciicauda are the parental species (Fig 2, Table 1). The mitochondrial markers had a total of 2085 base pairs (bps), 901 bps for the ND2 gene (17 variable sites), 385 bps for ND3 (13 variable sites), and 799 bps for COI (07 variable sites). We found no insertion/deletions (indels), stop codons or ambiguous peaks in the electropherograms of these markers, confirming their mitochondrial origin. The nuclear markers generated a database of $1566 \mathrm{bps}$, with $390 \mathrm{bps}$ for the GAPDH-I3, 537 bps for the FGB-I5, and 639 bps for the MB-I2. Overall, we found two polymorphisms sites in the GAPDH-I3 fragment and seven in the FGB-I5 sequence, although we found no polymorphic sites in the MB-I2. The concatenated genes were arranged in the following order: FGB-I5, COI, GAPDH-I3, MB-I2, ND2 and ND3, and the program indicated that the codons provided the best arrangement for the understanding of partitioning the data. We identified the GTR+I+G model as the optimum evolutionary model for the FGB-I5 sequences, the HKY $+\mathrm{I}+\mathrm{G}$ model for the $\mathrm{COI}$ gene (codon 1), the $\mathrm{K} 80+\mathrm{I}$ for $\mathrm{COI}$ (codon 2), and the F81 model for COI (codon 3). We also identified the F81+I model as the optimum for the GAPDH-I3 sequences, the F81 model for MB-I2, the HKY+I model for ND2 (codon 1), the F81 model for ND2 (codon 2), and the HKY for the ND2 (codon 3) sequence, as well as the HKY for the ND3 sequence (codons 1 and 2) and the K80 model for ND2 (codon 3). 
102 congruent, with two main clades, one that groups the P. aureola specimens and the hybrid (Pfa40), and the other

103 that includes the P. fasciicauda specimens. The topology based on the nuclear data alone (not shown) did not

104 provide a clear phylogenetic interpretation of the two species, given that the intrageneric variation in the nuclear

105 genes did not differentiate P. fasciicauda from $P$. aureola. Given this, the potential hybrid did not present

106 heterozygous sites that allowed the contribution of the parental ancestors to be interpreted. This precludes the

107 confirmation of P. fasciicauda as the paternal lineage, based on the genetic data. All the sequences generated in

108 the present study were deposited in GenBank (www. ncbi.nlm.nih.gov) under access numbers MN128472

109 through MN128514 for mitochondrial genes and MN166326 through MN166360 for nuclear genes (Online

110 Resource 1).

112 Discussion

113 Based on the integrated analysis of morphological, molecular, and zoogeographic data, we conclude

114 that the hybrid specimen was the product of a process of hybridization between Pipra fasciicauda and Pipra

115 aureola, with a subsequent introgression event involving the $P$. aureola lineage, given that the specimen in

116 question presents more morphological similarities with $P$. aureola. This indicates the possible existence of a

117 sympatric zone between the two taxa, given that a specimen of $P$. fasciicauda (Pfa41) was collected at the same

118 site as the potential hybrid (Fig 1), which was previously considered to be part of the geographic distribution of

119 only P. fasciicauda. Sympatry between closely-related piprids has been reported previously in the Amazonian

120 basin. In particular, this species is distributed in the region of the mouth of the Tapajós River (Haffer 1970,

121 1997), and the lower Xingu and Tocantins rivers (Ridgely and Tudor 1994), which is the region where the

122 potential hybrid analyzed in the present study was collected. However, no integrated analysis of the

123 morphological and molecular data had been applied previously to specimens from this region to confirm the

124 possible existence of interspecific hybrids. Haffer (1970) concluded that an ample hybrid zone between $P$.

125 aureola and P. fasciicauda certainly did not exist, but that the occurrence of isolated hybrids in contact zones

126 may eventually be detected. The results of the present study corroborate this hypothesis.

127 Interspecific hybridization in the genus Pipra was confirmed by Haffer (1970), who concluded that the

128 morphological description of a hybrid, denominated $P$. heterocerca, was in fact the result of a cross between $P$.

129 aureola and P. filicauda. The hybrid described in the present study, which appears to be the result of the

130 crossing of $P$. fasciicauda and $P$. aureola, provides additional evidence that this type of hybridization is not 
131 unusual in this genus. Some authors have discussed the circumstances that may promote heterospecific mating.

132 Aspects of the behavior and evolution of P. fasciicauda and P. aureola may have facilitated hybridization, in

133 particular, the similarities of their prenuptial rituals, which include the formation of leks and the elaborate

134 courtship behavior, together with the morphological similarities of the different forms. Analyzing vocal

135 repertoires, Curé et al. (2010) found that closely-related species may interact and respond to each other, despite

136 their other differences. As sister taxa, it seems likely that P. fasciicauda and P. aureola will have similar

137 vocalizations (Sick 1997), and PVC conducted tests (unpublished data) of song recognition in these two manakin

138 species (P. fasciicauda and P. aureola) and in hybrids from the Acará area, and obtained high rates of response

139 from hybrids to the songs and calls of both parent species, as well as positive responses using records of $P$.

140 fasciicauda and P. aureola to attract each other. Alatalo et al. (1990) also highlighted a combination of plumage

141 and vocal traits that contribute to hybridization, by causing errors in the recognition of conspecific males.

142 Our analysis on the morphology of the hybrid indicates a plumage pattern shared by $P$. aureola and $P$.

143 fasciicauda, with more characters being similar to $P$. aureola. The genetic data also indicated that this species

144 represented the maternal lineage. This suggests that, following hybridization, a process of introgression

145 occurred through secondary crosses with the $P$. aureola lineage. It thus seems likely that the hybrid is not the

146 product of a first generation cross, given that the only trait it shares with P. fasciicauda is the white band on the

147 tail, which is never observed in P. aureola. Introgression events have been reported in manakins (Dias et al.

148 2018; Weir et al. 2015), which indicates that phylogenetic proximity and recent divergence times facilitate the

149 maintenance of the fertility of the hybrids, and the subsequent occurrence of introgression events.

150 We emphasize the importance of understanding how the efficacy of interspecific sexual interactions

151 influences the evolution of a hybrid zone, especially given that the potential backcrossing of hybrids with either

152 parent species may eventually lead to introgression (Rezende et al. 2013). In this case, hybridization and

153 introgression are mechanisms that may have a direct influence on the evolution of this bird group and,

154 depending on the effectiveness of pre- and post-zygotic barriers, may also affect genetic variation and speciation,

155 creating fundamental difficulties for the delimitation of taxa and the interpretation of their phylogenetic

156 relationships (Toews et al. 2018, Dias et al. 2018). 
161 Alatalo R, Eriksson D, Gustafsson L, Lundberg A (1990) Hybridization between pied and collared flycatchers:

162

163

164

165

166

167

168

169

170

171

172

173

174

175

176

177

178

179

180

181

182

183

184

185

186

187

188

sexual selection and speciation theory. Journal of Evolutionary Biology 3:375-389

Brumfield RT, Jernigan RW, McDonald DB, Braun JM (2001) Evolutionary implications of divergent clines in an avian (Manacus: Aves) hybrid zone. Evolution 55:2070-2087

Curé C, Aubin T, Mathevon N (2010) Intra-sex vocal interactions in two hybridizing seabird species (Puffinus sp.). Behavioral Ecology Sociobiology 64:1823-1837

De Kort SR, Den Hartog PM, Ten Cate C (2002) Vocal signals, isolation and hybridization in the vinaceous dove (Streptopelia vinacea) and the ring-necked dove (S. capicola). Behavioral Ecology Sociobiology 51:378-385

Dias C, Lima KA, Araripe J, Aleixo A, Vallinoto M, Sampaio I, Schneider H, Rêgo PS (2018) Mitochondrial introgression obscures phylogenetic relationships among manakins of the genus Lepidothrix (Aves: Pipridae). Molecular Phylogenetics and Evolution 126:314-320

Gill F and D Donsker (Eds) (2019) IOC World Bird List (v 9.2). Doi 10.14344/IOC.ML.9.2. http://www.worldbirdnames.org/. Accessed 01 July 2019

Grant PR, Grant BR (1992) Hybridization of Bird Species. Science 256:193-197

Graves GR (1993) A new hydrid manakin (Dixiphia pipra $\times$ Pipra filicauda) (Aves: Pipridae) from the Andean foothills of eastern Ecuador. Proceedings of The Biological Society of Washington 106:436-441

Haffer J (1970) Art-Entstehung bei einigen Waldvögeln Amazoniens. Journal Für Ornithologie 111:285-331

Haffer J (1997) Alternative models of vertebrate speciation in Amazonia: an overview. Biodiversity and Conservation 6:451-476

Hall TA (1999) BIOEDIT: a user-friendly biological sequence alignment editor and analysis program for Windows 95/98/NT. Nucleic Acids Symposium Series 41:95-98

Huelsenbeck JP, Ronquist F (2001) MrBayes: Bayesian inference of phylogeny. Bioinformatics 17:754-755. https://doi.org/10.1093/bioinformatics/17.8.754

Lanfear RB, Calcott SY, Ho S (2012) Guindon. Partitionfinder: combined selection of partitioning schemes and substitution models for phylogenetic analyses. Molecular Biology and Evolution 29:1695-1701

Novaes FC, Lima MFC (2009) Aves da Grande Belém: municípios de Belém e Ananindeua, Pará. Museu

Paraense Emílio Goeldi, Belém, Brasil

Parkes KC (1961) Intergeneric hybrids in the family Pipridae. The Condor, 63:345-350 
189 Rezende MA, Vasconcelos MF, Nogueira W, Silva JC, Becho DP, Silva LF, Souza TO (2013) Novas Ocorrências

190 de Híbridos entre Chiroxiphia caudata e Antilophia galeata em Minas Gerais, Brasil, com a Primeira Descrição

191 de uma Fêmea Híbrida e Comentários sobre os Riscos da Hibridação. Atualidades Ornitológicas 174:33-39

192 Ridgely RS, Tudor G (1994) The Birds of South America. The Suboscine Passerines. Austin, United States of

193 America: University of Texas Press 2

194 Sick H (1997) Ornitologia Brasileira. Nova Fronteira, Rio De Janeiro

195 Smithe FB (1975) Naturalist's color guide. American Museum of Natural History, New York

196 Toews DPL, Walsh J, Campagna L (2018) Population Genomics of Birds: Evolutionary History and Conservation.

197 In: Population Genomics. Springer, Cham pp.1-40

198 Vaidya G, Lohman DJ, Meier R (2011) SequenceMatrix: concatenation software for the fast assembly of multi-

199 gene datasets with character set and codon information. Cladistics 27:171-180

200 Weir JT, Faccio MS, Pulido-Santacruz P, Barrera-Guzmán AO, Aleixo A (2015) Hybridization in headwater

201 regions, and the role of rivers as drivers of speciation in Amazonian birds. Evolution 69:1823-1834 
204 Fig 1 Geographic distribution of Pipra fasciicauda (blue) and Pipra aureola (red), showing the collecting sites

205 of the genetic data analyzed in the present study (Online Resource 1) and the topology of the Maximum

206 Likelihood and Bayesian Inference analyses of Pipra fasciicauda, Pipra aureola and the potential hybrid, based

207 on the multilocus data (ND2, ND3, COI, FGB-I5, MB-I2, GAPDH-I3) with Pipra filicauda as the outgroup. The

208 numbers within parentheses correspond to those of the collecting sites identified in the Online Resource section,

209 and the inset in the upper right portion of the map is a closeup of the region of Acará, where the specimens of the

210 potential hybrid and typical P. fasciicauda were collected. Photographs are provided in the phylogenetic tree to

211 show the parental species and the potential hybrid, Pipra aureola, outlined in red (credit: Ciro Albano), Pipra

212 fasciicauda, outlined in blue, and the potential hybrid from the Acará region, outlined in green (credit: Pablo

213 Vieira Cerqueira). The numbers above and below the branches correspond to the nonparametric bootstrap and

214 posterior probabilities, respectively. The species distribution shape files were adapted from BirdLife

215 International-Data Zone

216

217 Fig 2 Specimens showing plumage characters of each parental species, with the red and blue colors representing

218 Pipra aureola and Pipra fasciicauda, respectively, and the potential hybrid in green. A) Dorsal view, B) Ventral

219 view, and C) Closeups of the dorsal portion of the tail, showing the pattern of the white band: P. fasciicauda

220 presents a complete white band, $P$. aureola lacks the band, and the potential hybrid presents an incomplete band

221 with white marks on only the three outer rectrices. Voucher numbers: Pipra fasciicauda (MPEG 35883), Hybrid

222 individual (MPEG 82869) and Pipra aureola (MPEG 47486) 
Table 1 Comparison of the plumage coloration of Pipra fasciicauda, Pipra aureola, and the potential hybrid, including the crown, throat, breast, flanks, and the presence of the white band on the tail.

\begin{tabular}{|c|c|c|c|c|}
\hline & & Pipra fasciicauda & Hybrid & Pipra aureola \\
\hline Crown & & $\begin{array}{l}\text { Geranium (\#12) and } \\
\text { Orange Yellow (\#18) }\end{array}$ & Geranium (\#12) & Geranium (\#12) \\
\hline Throat & & $\begin{array}{l}\text { Orange Yellow (\#18) } \\
\text { finelly tinged of Flame } \\
\text { Scarlet (\#15) }\end{array}$ & Flame Scarlet (\#15) & Flame Scarlet (\#15) \\
\hline Breast & & Flame Scarlet (\#15) & Geranium (\#12) & Geranium (\#12) \\
\hline Flanks & & Orange Yellow (\#18) & $\begin{array}{l}\text { Jet Black (\#89) Less } \\
\text { extensive than in } P . \\
\text { aureola }\end{array}$ & Jet Black (\#89) \\
\hline \multirow{2}{*}{$\begin{array}{l}\text { Presence } \\
\text { of white } \\
\text { tail bands }\end{array}$} & Dorsal view & Yes & $\begin{array}{l}\text { No (Only in the three } \\
\text { outer rectrices) }\end{array}$ & No \\
\hline & Ventral view & Yes & Yes & No \\
\hline
\end{tabular}




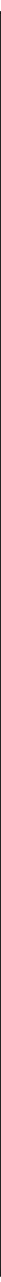




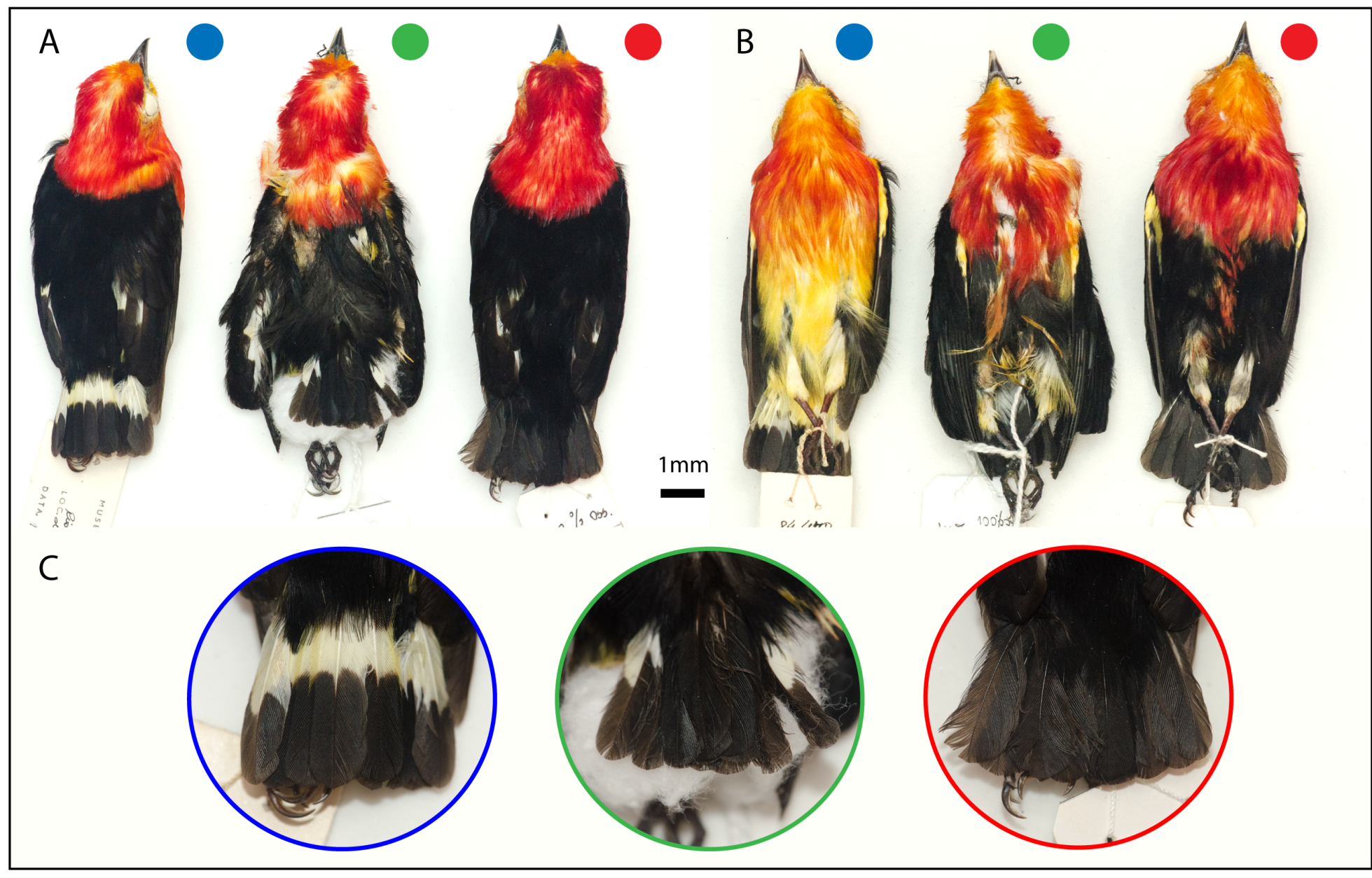


Analyses of plumage coloration and genetic variation confirm the hybridization of Pipra fasciicauda and Pipra aureola in the Brazilian Amazon basin

\author{
Journal of Ornithology \\ Larissa Sampaio $^{1}$, Dnilson Oliveira Ferraz ${ }^{1}$, Ana Carolina Moreira da Costa $^{1}$, Alexandre Aleixo ${ }^{2}$, Pablo \\ Cerqueira $^{3}$, Péricles Sena do Rêgo ${ }^{1,4}$.
}

${ }^{1}$ Institute of Coastal Studies, Universidade Federal do Pará, Bragança, Pará, Brazil;

${ }^{4}$ Correspondence and current address: Péricles Sena do Rêgo, Laboratório de Genética e Conservação, Campus Universitário de Bragança, Universidade Federal do Pará, Bragança-PA, 68600-000, Brazil, Telephone number: 5591 34251209, e-mail address: periclessena@yahoo.com.br 
Online Resource 1. The Pipra aureola and Pipra fasciicauda specimens analyzed in the present study and Pipra filicauda used as out-group, with information on the identification of the specimens and the markers sequenced with their respective GenBank access codes. The markers not sequenced in each individual are indicated by a minus (-) sign. The specimens were obtained from the ornithological collections of the Goeldi Museum (Museu Paraense Emílio Goeldi: MPEG*) in Belém and the National Institute for Amazonian Research (INPA) in Manaus, Brazil.

\begin{tabular}{|c|c|c|c|c|c|c|c|c|c|c|c|c|}
\hline $\begin{array}{l}\text { Collect } \\
\text { point } \\
\text { (Map) }\end{array}$ & Taxon & $\begin{array}{l}\text { Laboratory } \\
\text { code }\end{array}$ & Tombo & Collection & Locality & Geographical coordinates & ND2 & ND3 & $\mathrm{COI}$ & FGB-I5 & MB-I2 & GAPDH-I3 \\
\hline 01 & P. fasciicauda & $\mathrm{Pfa01}$ & & MPEG* & $\begin{array}{c}\text { Brasil, Ceará, } \\
\text { Guaramiranga, Serra de } \\
\text { Baturité, Parque das Trilhas }\end{array}$ & $04^{\circ} 16^{\prime} 06^{\prime \prime} \mathrm{S} ; 38^{\circ} 56^{\prime} 14^{\prime \prime} \mathrm{W}$ & $\begin{array}{l}\text { MN128 } \\
475\end{array}$ & $\begin{array}{l}\text { MN128 } \\
506\end{array}$ & $\begin{array}{l}\text { MN1 } \\
2849 \\
1\end{array}$ & $\begin{array}{l}\text { MN166 } \\
352\end{array}$ & $\begin{array}{c}\text { MN166 } \\
326\end{array}$ & MN166340 \\
\hline 01 & P. fasciicauda & $\mathrm{Pfa02}$ & & MPEG* & $\begin{array}{c}\text { Brasil, Ceará, } \\
\text { Guaramiranga, Serra de } \\
\text { Baturité, Parque das Trilhas }\end{array}$ & $04^{\circ} 16^{\prime} 06^{\prime \prime} \mathrm{S} ; 38^{\circ} 56^{\prime} 14^{\prime \prime} \mathrm{W}$ & $\begin{array}{l}\text { MN128 } \\
476\end{array}$ & $\begin{array}{l}\text { MN128 } \\
507\end{array}$ & $\begin{array}{l}\text { MN1 } \\
2849 \\
2\end{array}$ & $\begin{array}{l}\text { MN166 } \\
353\end{array}$ & $\begin{array}{c}\text { MN166 } \\
327\end{array}$ & MN166341 \\
\hline 01 & P. fasciicauda & $\mathrm{Pfa} 03$ & & MPEG* & $\begin{array}{c}\text { Brasil, Ceará, } \\
\text { Guaramiranga, Serra de } \\
\text { Baturité, Parque das Trilhas }\end{array}$ & $04^{\circ} 16^{\prime} 06^{\prime \prime} \mathrm{S} ; 38^{\circ} 56^{\prime} 14^{\prime \prime} \mathrm{W}$ & $\begin{array}{l}\text { MN128 } \\
477\end{array}$ & $\begin{array}{l}\text { MN128 } \\
508\end{array}$ & $\begin{array}{l}\text { MN1 } \\
2849 \\
3\end{array}$ & $\begin{array}{l}\text { MN166 } \\
354\end{array}$ & $\begin{array}{c}\text { MN166 } \\
328\end{array}$ & MN166342 \\
\hline 01 & P. fasciicauda & $\mathrm{Pfa} 04$ & & MPEG* & $\begin{array}{c}\text { Brasil, Ceará, } \\
\text { Guaramiranga, Serra de } \\
\text { Baturité, Parque das Trilhas }\end{array}$ & $04^{\circ} 16^{\prime} 06^{\prime \prime} \mathrm{S} ; 38^{\circ} 56^{\prime} 14^{\prime \prime} \mathrm{W}$ & $\begin{array}{l}\text { MN128 } \\
478\end{array}$ & $\begin{array}{l}\text { MN128 } \\
509\end{array}$ & $\begin{array}{l}\text { MN1 } \\
2849 \\
4\end{array}$ & $\begin{array}{l}\text { MN166 } \\
355\end{array}$ & $\begin{array}{l}\text { MN166 } \\
329\end{array}$ & MN166343 \\
\hline 01 & P. fasciicauda & Pfa05 & & MPEG* & $\begin{array}{c}\text { Brasil, Ceará, } \\
\text { Guaramiranga, Serra de } \\
\text { Baturité, Parque das Trilhas }\end{array}$ & $04^{\circ} 16^{\prime} 06^{\prime \prime} \mathrm{S} ; 38^{\circ} 56^{\prime} 14^{\prime \prime} \mathrm{W}$ & $\begin{array}{l}\text { MN128 } \\
479\end{array}$ & $\begin{array}{l}\text { MN128 } \\
510\end{array}$ & $\begin{array}{l}\text { MN1 } \\
2849\end{array}$ & $\begin{array}{l}\text { MN166 } \\
356\end{array}$ & $\begin{array}{l}\text { MN166 } \\
330\end{array}$ & MN166344 \\
\hline 02 & $\begin{array}{l}\text { Ambiguous } \\
\text { individual }\end{array}$ & Pfa40 & & MPEG* & $\begin{array}{c}\text { Brasil, Pará, Acará, } \\
\text { Comunidade Menino Jesus }\end{array}$ & $01^{\circ} 29^{\prime} 14^{\prime \prime} \mathrm{S} ; 48^{\circ} 18^{\prime} 57^{\prime \prime} \mathrm{W}$ & $\begin{array}{l}\text { MN128 } \\
480\end{array}$ & $\begin{array}{l}\text { MN128 } \\
511\end{array}$ & $\begin{array}{l}\text { MN1 } \\
2849 \\
6\end{array}$ & $\begin{array}{l}\text { MN166 } \\
357\end{array}$ & $\begin{array}{c}\text { MN166 } \\
331\end{array}$ & MN166345 \\
\hline 02 & P. fasciicauda & Pfa41 & & MPEG* & $\begin{array}{c}\text { Brasil, Pará, Acará, } \\
\text { Comunidade Menino Jesus }\end{array}$ & $01^{\circ} 29^{\prime} 14^{\prime \prime} \mathrm{S} ; 48^{\circ} 18^{\prime} 57^{\prime \prime} \mathrm{W}$ & - & $\begin{array}{l}\text { MN128 } \\
512\end{array}$ & $\begin{array}{l}\text { MN1 } \\
2849 \\
7\end{array}$ & $\begin{array}{l}\text { MN166 } \\
358\end{array}$ & $\begin{array}{c}\text { MN166 } \\
332\end{array}$ & MN166346 \\
\hline
\end{tabular}




\begin{tabular}{|c|c|c|c|c|c|c|c|c|c|c|c|c|}
\hline 03 & P. fasciicauda & $\mathrm{Pfa} 42$ & 55524 & MPEG* & $\begin{array}{l}\text { Rio Xingu, Altamira, Ilha da } \\
\text { Taboca, UHE Belo Monte }\end{array}$ & $3^{\circ} 22^{\prime} 63^{\prime \prime} \mathrm{S}, 51^{\circ} 57^{\prime} 57^{\prime \prime} \mathrm{W}$ & $\begin{array}{l}\text { MN128 } \\
481\end{array}$ & $\begin{array}{l}\text { MN128 } \\
513\end{array}$ & $\begin{array}{l}\text { MN1 } \\
2849 \\
8\end{array}$ & $\begin{array}{l}\text { MN166 } \\
359\end{array}$ & $\begin{array}{c}\text { MN166 } \\
333\end{array}$ & MN166347 \\
\hline 03 & P. fasciicauda & Pfa43 & 55525 & MPEG* & $\begin{array}{l}\text { Rio Xingu, Altamira, Ilha da } \\
\text { Taboca UHE Belo Monte }\end{array}$ & $3^{\circ} 22^{\prime} 83^{\prime \prime} \mathrm{S}, 51^{\circ} 57^{\prime} 15^{\prime \prime} \mathrm{W}$ & $\begin{array}{l}\text { MN128 } \\
482\end{array}$ & $\begin{array}{l}\text { MN128 } \\
514\end{array}$ & $\begin{array}{l}\text { MN1 } \\
2849 \\
9\end{array}$ & $\begin{array}{l}\text { MN166 } \\
360\end{array}$ & $\begin{array}{c}\text { MN166 } \\
334\end{array}$ & MN166348 \\
\hline 04 & P. fasciicauda & Pfa87 & & MPEG* & Primavera, Pará & & $\begin{array}{l}\text { MN128 } \\
483\end{array}$ & - & $\begin{array}{c}\text { MN1 } \\
2850 \\
0\end{array}$ & - & - & - \\
\hline 05 & P. aureola & Pau01 & A8491 & MPEG* & $\begin{array}{c}\text { Brasil, Pará, Ilha do Marajó, } \\
\text { Município de Chaves, } \\
\text { Fazenda Anjos }\end{array}$ & $00^{\circ} 11^{\prime} 18,6 " \mathrm{~S} ; 49^{\circ} 53^{\prime} 11,3 " \mathrm{~W}$ & $\begin{array}{l}\text { MN128 } \\
472\end{array}$ & - & $\begin{array}{l}\text { MN1 } \\
2848 \\
8\end{array}$ & $\begin{array}{l}\text { MN166 } \\
349\end{array}$ & $\begin{array}{c}\text { MN166 } \\
335\end{array}$ & MN166337 \\
\hline 05 & P. aureola & Pau02 & 58085 & MPEG* & $\begin{array}{c}\text { Brasil, Pará, Ilha do Marajó, } \\
\text { Município de Chaves, } \\
\text { Fazenda Anjos }\end{array}$ & $00^{\circ} 11^{\prime} 18,6 " \mathrm{~S} ; 49^{\circ} 53^{\prime} 11,3^{\prime \prime} \mathrm{W}$ & $\begin{array}{l}\text { MN128 } \\
473\end{array}$ & - & $\begin{array}{l}\text { MN1 } \\
2848 \\
9\end{array}$ & $\begin{array}{l}\text { MN166 } \\
350\end{array}$ & - & MN166338 \\
\hline \multirow[t]{4}{*}{06} & P. aureola & Pau05 & 66561 & MPEG* & $\begin{array}{l}\text { Brasil, Pará, Almeirim, } \\
\text { FLOTA do Paru }\end{array}$ & $00^{\circ} 56^{\prime} \mathrm{S} ; 53^{\circ} 14^{\prime} \mathrm{W}$ & $\begin{array}{l}\text { MN128 } \\
474\end{array}$ & $\begin{array}{l}\text { MN128 } \\
505\end{array}$ & $\begin{array}{l}\text { MN1 } \\
2849 \\
0\end{array}$ & $\begin{array}{l}\text { MN166 } \\
351\end{array}$ & $\begin{array}{c}\text { MN166 } \\
336\end{array}$ & MN166339 \\
\hline & P. filicauda & Pfi12 & $\begin{array}{l}\text { INPA A } \\
611\end{array}$ & INPA & $\begin{array}{l}\text { ESEC Juami-Japurá; boca } \\
\text { do Rio Juami; margem } \\
\text { direita do Rio Japurá, ca } 70 \\
\text { km WNW Japurá }\end{array}$ & & $\begin{array}{l}\text { MN128 } \\
484\end{array}$ & - & $\begin{array}{l}\text { MN1 } \\
2850 \\
1\end{array}$ & - & - & - \\
\hline & P. filicauda & Pfi13 & $\begin{array}{l}\text { INPA A } \\
962\end{array}$ & INPA & $\begin{array}{c}\text { Ilha do Barbado, Rio } \\
\text { Solimões, ca } 60 \text { km E de } \\
\text { Tefé }\end{array}$ & & $\begin{array}{l}\text { MN128 } \\
485\end{array}$ & - & $\begin{array}{l}\text { MN1 } \\
2850 \\
2\end{array}$ & - & - & - \\
\hline & P. filicauda & Pfi15 & $\begin{array}{l}\text { INPA A } \\
1052\end{array}$ & INPA & $\begin{array}{c}\text { Parque Nacional Viruá, } \\
\text { margem direita do Rio } \\
\text { Anauá, localidade } \\
\text { "Campinho" }\end{array}$ & & $\begin{array}{l}\text { MN128 } \\
486\end{array}$ & - & $\begin{array}{l}\text { MN1 } \\
2850 \\
3\end{array}$ & - & - & - \\
\hline
\end{tabular}


Caracaraí; Vista Alegre;

margem esquerda do Rio

Branco; ca 26 Km W da

base do Parque Nacional do

MN128

487
$\mathrm{MN}$

2850 
Analyses of plumage coloration and genetic variation confirm the hybridization of Pipra fasciicauda and Pipra aureola in the Brazilian Amazon basin

\section{Journal of Ornithology}

Larissa Sampaio $^{1}$, Dnilson Oliveira Ferraz ${ }^{1}$, Ana Carolina Moreira da Costa ${ }^{1}$, Alexandre Aleixo ${ }^{2}$, Pablo Cerqueira $^{3}$, Péricles Sena do Rêgo ${ }^{1,4}$.

${ }^{1}$ Institute of Coastal Studies, Universidade Federal do Pará, Bragança, Pará, Brazil;

${ }^{4}$ Correspondence and current address: Péricles Sena do Rêgo, Laboratório de Genética e Conservação, Campus Universitário de Bragança, Universidade Federal do Pará, Bragança-PA, 68600-000, Brazil, Telephone number: 5591 34251209, e-mail address: periclessena@yahoo.com.br 
Online Resource 2 Genes analyzed in the present study, with their respective primers and nucleotide sequences

\begin{tabular}{|c|c|c|c|}
\hline Gene & Primer & Sequence & Reference \\
\hline \multirow{2}{*}{ ND3 } & L10755 & 5' GACTTCCAATCTTTAAAATCTGG 3' & Chesser 1999. \\
\hline & H11151 & 5' GATTTGTTGAGCCGAAATCAAC 3' & Chesser 1999. \\
\hline \multirow{2}{*}{ ND2 } & L5216 & 5' GGCCCATACCCGRAAAT 3' & Hackett 1996. \\
\hline & H6313 & 5' CTCTTATTTAAGGCTTTGAAGGC 3' & Hackett 1996. \\
\hline \multirow{2}{*}{$\mathrm{COI}$} & FISHF1 & 5' TCAACCAACCACAAAGACATTGGCAC 3' & Ward et al. 2005. \\
\hline & COIA & 5' AGTATAAGCGTCTGGGTAGTC 3' & Palumbi and Benzie 1991. \\
\hline \multirow{2}{*}{ FGB-I5 } & FIB5 & 5' CGCCATACAGAGTATACTGTGACA 3' & Driskell and Cristidis 2004. \\
\hline & FIB6 & 5' GCCATCCTGGCGATTCTGAA 3' & Driskell and Cristidis 2004. \\
\hline \multirow{2}{*}{ MB-I2 } & MYO2 & 5' GCCACCAAGCACAAGATCCC 3' & Heslewood et al. 1998. \\
\hline & MYO3F & 5' GCAAGGACCTTGATAATGACTT 3' & Slade et al. 1993. \\
\hline \multirow{2}{*}{ GAPDH-I3 } & G3PDH13b & 5' TCCACCTTTGATGCGGGTGCTGGCAT 3' & Fjeldsa et al. 2003. \\
\hline & G3PDH14b & 5' AAGTCCACAACACGGTTGCTGTA 3' & Fjeldsa et al. 2003. \\
\hline
\end{tabular}


Analyses of plumage coloration and genetic variation confirm the hybridization of Pipra fasciicauda and Pipra aureola in the Brazilian Amazon basin

\section{Journal of Ornithology}

Larissa Sampaio $^{1}$, Dnilson Oliveira Ferraz ${ }^{1}$, Ana Carolina Moreira da Costa $^{1}$, Alexandre Aleixo ${ }^{2}$, Pablo Cerqueira $^{3}$, Péricles Sena do Rêgo ${ }^{1,4}$.

${ }^{1}$ Institute of Coastal Studies, Universidade Federal do Pará, Bragança, Pará, Brazil;

${ }^{4}$ Correspondence and current address: Péricles Sena do Rêgo, Laboratório de Genética e Conservação, Campus Universitário de Bragança, Universidade Federal do Pará, Bragança-PA, 68600-000, Brazil, Telephone number: 5591 34251209, e-mail address: periclessena@yahoo.com.br 


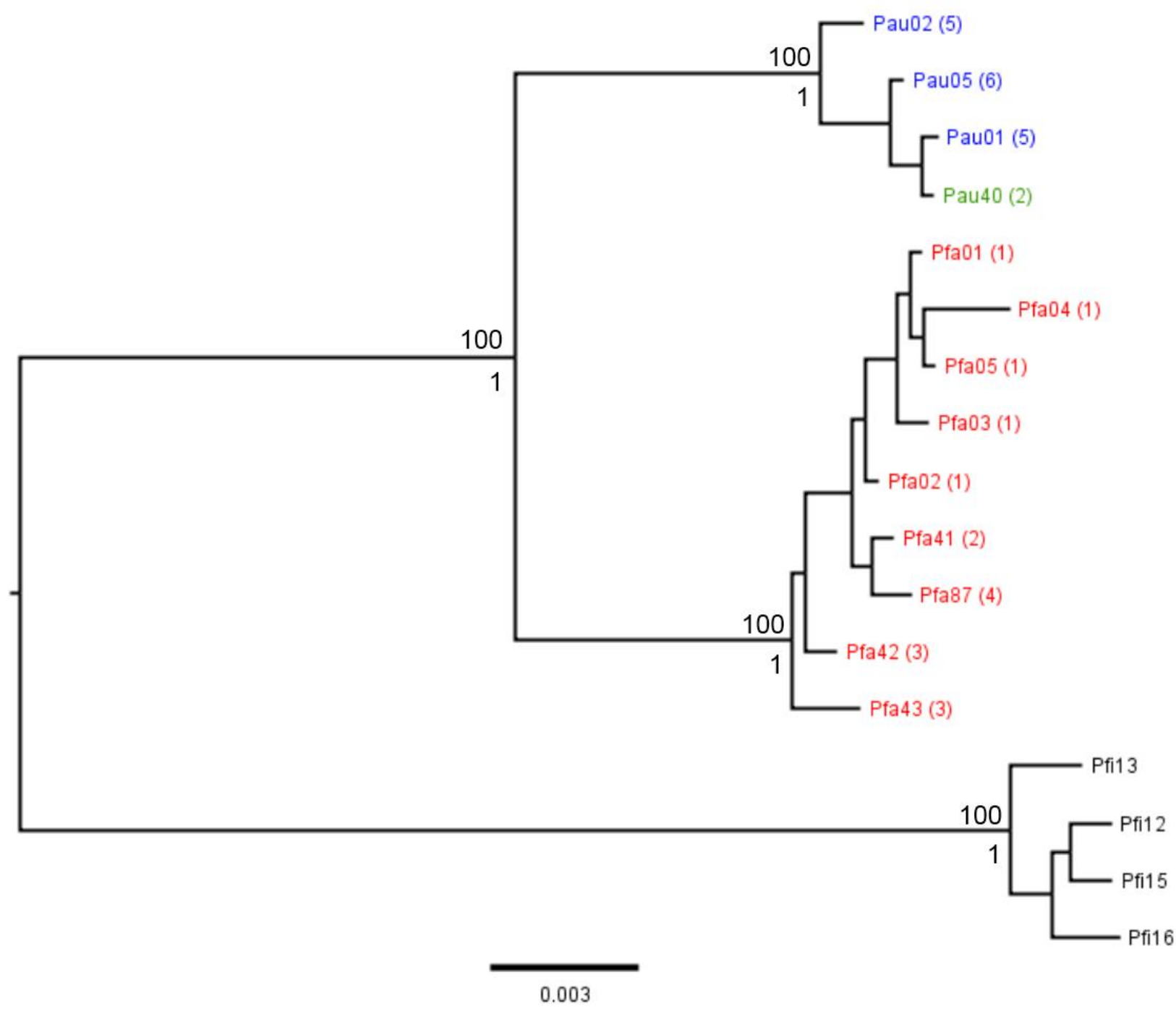

Online Resource 3 Bayesian inference topology of Pipra fasciicauda (Pfa) and Pipra aureola (Pau), with a posteriori values below the branches and bootstrap values above.

The topology was rooted by Pipra filicauda (Pfi) 